\title{
CHARACTERISTICS OF THE FISHING INDUSTRY IN LATVIA
}

\author{
Liga Proskina ${ }^{1}$, Dr.oec.; Irina Pilvere ${ }^{2}$, Dr.oec.; Aleksejs Nipers ${ }^{3}$, Dr.oec.; \\ Mihails Silovs ${ }^{4}$; MSc \\ 1,2,3,4 Faculty of Economics and Social Development, Latvia University of Life Sciences and Technologies
}

\begin{abstract}
Fisheries and aquaculture remain important sources of food, nutrition, income and livelihoods for hundreds of millions of people around the world. In the EU, the development of fisheries is affected by the Common Fisheries Policy which aims to ensure that fishing and aquaculture are environmentally, economically and socially sustainable and that they provide a source of healthy food for EU citizens. In Latvia, the fisheries industry is related to a rational and sustainable use of living natural resources in its economic zone, territorial waters and internal waters. Therefore, research aim is to examine the key characteristics of the fishing industry in Latvia. To achieve the aim, the following specific research tasks are defined: 1) to examine the characteristics of the fishing fleets of EU Member States; 2) to analyse total catch volumes and the performance of top 10 fishing enterprises in Latvia. The present research analysed the fishing fleets of EU Member States, which are affected by fleet capacity management measures, catch quotas for Latvia, catch volumes in the Baltic Sea and the Gulf of Riga in the period 2014-2017 as well as the key performance indicators of the top 10 fishing enterprises of Latvia. The research has discovered that the fishing enterprises of Latvia are affected by catch quotas for the key fish species that were reduced on average by 1-57 \% during the period 2014-2017. The top 10 fishing enterprises turnover in 2016 increased by $60.7 \%$ compared with 2014 and by $27.7 \%$ compared with 2015 , but in 2016 only four made profit.
\end{abstract}

Key words: fishing, fishing fleet, catch quotas, indicators

JEL code: Q22

\section{Introduction}

Fisheries and aquaculture remain important sources of food, nutrition, income and livelihoods for hundreds of millions of people around the world. International trade plays a major role in the fisheries and aquaculture sector as an employment creator, food supplier, income generator, and contributor to economic growth and development, as well as to food and nutrition security. Fish and fishery products represent one of the most-traded segments of the world food sector (FAO, 2016). However, fishing is one of the most risky occupations worldwide. Regarding the economic importance of the sector, it employs more than 37 million direct workers worldwide (not including aquaculture or processing industries). Fishing influence is especially relevant in the less developed countries, where primary sectors have a prevalent role. Globally, fish trade activities have grown in the last years, with exports rising from 72 billion dollars in 2004 to 148 billion dollars in 2014 and imports rising from 76 billion dollars in 2004 to 140 billion dollars in 2014 (Gonzalez M. M., Bulian G., 2018). It has to be stressed that people involved in decision-making processes should understand why fish and fisheries are important for society, that is, be aware of the socio-cultural values that people associate with fisheries (Ignatius S., Haapasaari P., 2018).

In several EU regions the fishing sector plays a crucial role for employment and economic activity - in some European coastal communities as many as half the local jobs are in the fishing sector. The Common Fisheries Policy (CFP) aims to ensure that fishing and aquaculture are environmentally, economically and socially sustainable and that they provide a source of healthy food for EU citizens. Its goal is to foster a dynamic fishing industry and ensure a fair standard of living for fishing communities (European Commission, 2016).

In various countries, fishing plays an essential role, yet it faces serious challenges. For example, the fisheries industry has long been an important industry along the Norwegian coast. But...overcapacity was considered one of the main reasons behind the Norwegian fishing fleet's poor financial performance (Zhang D., Sikveland M., Hermansen Ø., 2018). The Icelandic fishing 
industry has had to deal with a reduced total catch for the past three decades. The industry has responded by reducing employment, closing factories and scrapping boats, thus significantly lowering the number of people working in the industry, especially in the processing component (Gunnlaugsson S.B., Saevaldsson H., 2016). The Belgian fishing sector is under pressure to demonstrate the sustainability of its fishing methods (Kindsa A., Sysa K. et al., 2016). Fisheries management in Northern Ireland uses a combination of catch restrictions (quota, minimum landing size), effort restrictions (days at sea, no weekend fishing), gear restrictions (minimum mesh size, square mesh panels), and spatial restrictions (the Cod Box). There are also voluntary stock management measures, such as v-notching berried lobsters (Yates K.L., 2014). In Sweden the importance of addressing forest owners' interests in development and management of fish and water resources is essential for successful policy programmes. Not only they own forests, they are a major group owning a water area with fishing rights (Laitila T., Paulrud A., Waldo S., 2018). Britain has a long history as a fishing nation and its waters are some of the most productive in Europe. But Brexit would involve compromise on many issues and the UK would be under pressure to be cooperative, especially in areas that more directly affect other EU Member States. Commercial fisheries are a typical example (Baldock D., Buckwell A. et al., 2016).

In Latvia the fisheries industry is related to a rational and sustainable use of living natural resources in its economic zone, territorial waters, and internal waters. The fisheries industry in Latvia represents three main fields of activity: fishing, fish processing, and aquaculture that to a great extent affects also the development of rural areas (Pilvere I., Upite I., 2011). In recent years, earnings in the fishing industry and aquaculture have increased, on average, by 3-6 \% a year, except in 2013 when the earnings decreased by $2 \%$ (Ministry of Agriculture, 2017a; b). Therefore, research aim is to examine the key characteristics of the fishing industry in Latvia. To achieve the aim, the following specific research tasks are defined: 1) to examine the characteristics of the fishing fleets of EU Member States; 2) to analyse total catch volumes and the performance of top 10 fishing enterprises in Latvia.

Methodology and data. Analysis, synthesis, the logical construction method, the induction and deduction methods were employed to execute the research tasks. Scientific literature review was used as well.

\section{Research results and discussion 1. Fishing industry in the European Union}

The total number of fishing vessels in the world in 2014 was estimated at about 4.6 million, very close to the figure for 2012 (FAO, 2016). EU fisheries management aims to achieve efficient fishing activities within an economically viable and competitive fisheries industry. Fleet capacity management is an essential tool for the CFP. The EU fishing fleet is very diverse, with vessels ranging from under six metres to over 75 . The EU is the fifth largest producer worldwide, accounting for about $3.2 \%$ of global fisheries and aquaculture production: $80 \%$ of the production comes from fisheries and $20 \%$ from aquaculture. (European Commission, 2016). The leading fishing countries in terms of volume are Spain, Denmark, the United Kingdom and France, which combined, account for more than half of EU catches (European Commission, 2016). Quota management in the EU began for the majority of commercial fish stocks with the first CFP implemented in 1983, a time when fish stocks were at low levels and fishing pressure was still high. The allocation of quotas among the EU Member States is largely determined by historic catch 
shares - the "relative stability" - of the Member States over a reference period (1973-78) just before the CFP was brought into force. Under this method, countries fishing in each other's waters during the reference period continue to have the right to do so (Carpenter G., 2016). Gradually fishing pressure has decreased for quota species and some fish stocks are now growing.

The maximum capacity of the fishing fleet for every EU Member State is set in accordance with the fisheries management framework established under the CFP. Among the EU Member States, eight countries dominate: Greece, Italy, Spain, Portugal, Croatia, France and the United Kingdom; their number of fishing vessels accounts for $78 \%$, their gross tonnage comprises $68 \%$ and their total vessel engine power represents $75 \%$ of the EU total. It has to be mentioned that the Netherlands with only $1 \%$ of the total fishing vessels in the EU accounts for $8 \%$ of the total gross tonnage and almost $5 \%$ of the total vessel engine power in the EU. The number of fishing vessels of Latvia represents $0.8 \%$ of the EU total, while in terms of gross tonnage the fishing fleet of Latvia makes up $2.5 \%$ of the EU total. This means that small-capacity vessels dominate in the fishing fleet (Table 1).

Characteristics of EU Member State fishing fleets in 2015

Table 1

\begin{tabular}{|l|c|c|c|c|c|c|}
\hline $\begin{array}{c}\text { Member } \\
\text { State }\end{array}$ & $\begin{array}{c}\text { Number of } \\
\text { fishing } \\
\text { vessels }\end{array}$ & $\begin{array}{c}\text { Propor- } \\
\text { tion, } \%\end{array}$ & $\begin{array}{c}\text { Gross } \\
\text { tonnage, Gt }\end{array}$ & $\begin{array}{c}\text { Propor- } \\
\text { tion, }\end{array}$ & $\begin{array}{c}\text { Engine power, } \\
\text { kW }\end{array}$ & Proportion, \% \\
\hline Greece & 15638 & 18.4 & 76573 & 4.7 & 449534 & 6.9 \\
\hline Italy & 12414 & 14.6 & 162749 & 9.9 & 1003301 & 15.5 \\
\hline Spain & 9572 & 11.2 & 354186 & 21.6 & 815872 & 12.6 \\
\hline Portugal & 8136 & 9.6 & 96596 & 5.9 & 359633 & 5.6 \\
\hline Croatia & 7540 & 8.9 & 52341 & 3.2 & 414618 & 6.4 \\
\hline France & 6964 & 8.2 & 171544 & 10.5 & 1001603 & 15.5 \\
\hline United & 6319 & 7.4 & 194683 & 11.9 & 787592 & 12.2 \\
\hline Kingdom & 2839 & 3.3 & 15613 & 1.0 & 160475 & 2.5 \\
\hline Finland & 2396 & 2.8 & 69607 & 4.2 & 224769 & 3.5 \\
\hline Irenmark & 2156 & 2.5 & 62331 & 3.8 & 189442 & 2.9 \\
\hline Bulgaria & 1989 & 2.3 & 6541 & 0.4 & 58043 & 0.9 \\
\hline Estonia & 1534 & 1.8 & 13225 & 0.8 & 43714 & 0.7 \\
\hline Germany & 1465 & 1.7 & 64221 & 3.9 & 141679 & 2.2 \\
\hline Sweden & 1357 & 1.6 & 30398 & 1.9 & 167214 & 2.6 \\
\hline Malta & 1005 & 1.2 & 7106 & 0.4 & 73106 & 1.1 \\
\hline Cyprus & 893 & 1.0 & 3502 & 0.2 & 40209 & 0.6 \\
\hline Poland & 874 & 1.0 & 26293 & 1.6 & 76256 & 1.2 \\
\hline Netherlands & 832 & 1.0 & 133995 & 8.2 & 312548 & 4.8 \\
\hline Latvia & 688 & 0.8 & 41403 & 2.5 & 46484 & 0.7 \\
\hline Slovenia & 169 & 0.2 & 597 & 0.0 & 8540 & 0.1 \\
\hline Romania & 152 & 0.2 & 870 & 0.1 & 6146 & 0.1 \\
\hline Lithuania & 144 & 0.2 & 41403 & 2.5 & 46484 & 0.7 \\
\hline Belgium & 78 & 0.1 & 14535 & 0.9 & 46289 & 0.7 \\
\hline Total & $\mathbf{8 5 1 5 4}$ & $\mathbf{1 0 0 . 0}$ & $\mathbf{1 6 4 0 3 1 2}$ & $\mathbf{1 0 0}$ & $\mathbf{6 4 7 3 5 5 1}$ & $\mathbf{1 0 0}$ \\
\hline Source: EUROSTAT & $\mathbf{2 0 1 7}$ & & & & & \\
\hline
\end{tabular}

It has to be noted that the length range of fishing vessels is very diverse - from less than $6 \mathrm{~m}$ to more than $75 \mathrm{~m}$ (Community Fishing..., 2017), and so is the range of gross tonnage (0.16-4407 $\mathrm{Gt}$ ). For example, the number of fishing vessels in the neighbouring country - Lithuania - accounts for only $0.2 \%$ of the EU total, while the gross tonnage represents $2.5 \%$, which indicates that the 
fishing fleet of Lithuania exploits larger-capacity vessels. Among the Baltic States, the largest fishing fleet with 1534 vessels is reported in Estonia, yet its gross capacity is only $32 \%$ and its total engine power is $94 \%$ of the total fishing fleet of Latvia. The average age of vessels used in fishing beyond the coastal zone is $\mathbf{2 7 . 2}$ years, while the average age of those used in the coastal zone is 26.4 years. During the course of time, the vessels have become obsolete and therefore cause greater risks to the environment as well as increase the maintenance and operational costs of the vessels (Ministry of Agriculture, 2016b).

In 2016 in Latvia, 57 vessels did fishing in the Baltic Sea and the Gulf of Riga beyond the coastal zone, 610 fishing boats - in the coastal zone and 12 vessels - on the high seas.

In Latvia, the State Environmental Service (SES) controls fishing done by the fishing vessels of Latvia in the waters of EU Member States and non-EU countries and in international waters in accordance with the legal framework. The SES grants licences for industrial fishing in the internal waters, for fishing in the coastal waters as well as international and third-country waters and for special purpose fishing. In 2016, according to the SES, the list of fishing vessels of Latvia included 43 cod fishing vessels and 24 vessels for fishing in the Gulf of Riga (SES, 2017a; b).

On 2 December 2016, the Ministry of Agriculture made decision No. 4.1-12/87 "On Industrial Fishing Limits and Procedures for Use thereof in the Baltic Sea and the Gulf of Riga beyond Coastal Waters in 2017", which stipulated that industrial fishing agreements for a lease of fishing rights, based on the limits set in the decision, would be concluded with 37 fishing enterprises in 2017 (Ministry of Agriculture, 2016a). However, the 2017 list of vessels authorised to do fishing in the Baltic Sea and the Gulf of Riga broken down by fish species and fishing site contained 64 fishing vessels.

\section{Key factors for the fishing industry in Latvia}

The fishing industry in Latvia depends on opportunities to do fishing in the Baltic Sea. However, it has to be taken into account that since 2005 the key initiative in regulating fishing and setting catch quotas in the Baltic Sea has belonged to the European Commission, as the EU Member States accounted for $95 \%$ of the total catch volume in the Baltic Sea. In 2013, the EU reformed its CFP, setting a target to increase fish reserves to a stable level until 2020. It is possible by means of very strict catch quotas. The amount of quotas to be allocated to the Member States is decided by the EU Council of Ministers of Agriculture and Fisheries (European Commission, 2016). The allocation of quotas to individual fishing companies is a Member State competence under the CFP (Pantzar M., 2016). The catch quotas in the Baltic Sea available to Latvia are distributed individually to every fishing entity, allowing the quotas to be exchanged and transferred, which contributes to efficiently exploiting the resources available to Latvia and achieving a catch volume as sustainable as possible (Ministry of Agriculture, 2017a; b).

The stocks of the most important fish species - cod, Baltic herring, sprat and salmon - in the Baltic Sea are estimate by the International Council for the Exploration of the Sea (ICES), which develops proposals for the sustainable exploitation of the fish stocks according to the Multiannual Baltic Sea Management Plan that was adopted by the Member States and the European Parliament (ICES, 2017).

In accordance with of Paragraph 4 of Section 11 of the Fishery Law of the Republic of Latvia (1995), the total catch quota allocated to Latvia in its territorial waters and economic zone waters as well as in the waters of other EU Member States and in international waters or in the waters of 
third countries, with which the EU has concluded agreements on fishing, is stipulated in the EU legal documents. The total catch quota in the territorial waters and economic zone waters of Latvia is divided into a quota for fishing in the Baltic Sea and the coastal waters of the Gulf of Riga and a quota for fishing in the waters beyond the coastal zone.

The division of waters into coastal waters and waters beyond the coastal zone is defined in accordance with the provisions stipulated in Cabinet Regulation of the Republic of Latvia No. 296 (2007) "Regulations regarding Commercial Fishing in the Territorial Waters and Economic Zone Waters". The total catch quota available to Latvia in 2017 was set by Council Regulation (EU) 2016/1903 of 28 October 2016 fixing for 2017 the fishing opportunities for certain fish stocks and groups of fish stocks applicable in the Baltic Sea and amending Regulation (EU) 2016/72. The fishing enterprises of Latvia have to take into account a decrease in fishing opportunities, as the only quota that was increased for 2017 , compared with the previous years, was for sprats $(+20 \%$ in comparison with 2014), while the quotas for cod, Baltic herring and salmon were decreased by $57 \%, 1 \%$ and $10 \%$, respectively, compared with 2014 (Table 2).

\section{Catch quotas for Latvia and catch volumes in the Baltic Sea and the Gulf}

Table 2 of Riga in 2014-2017

\begin{tabular}{|c|c|c|c|c|c|c|}
\hline Indicators & Cod & $\begin{array}{c}\text { Baltic } \\
\text { herring }\end{array}$ & $\begin{array}{l}\text { Incl. in the } \\
\text { Gulf of Riga }\end{array}$ & Sprats & Salmon* & Total \\
\hline \multicolumn{7}{|c|}{2014} \\
\hline Catch quota, t & 6642 & 22650 & 19335 & 32667 & 70 & 81364 \\
\hline Real catch volume, t & 2037 & 23315 & $x$ & 30758 & 4 & 56114 \\
\hline Volume as a \% of quota & 30.6 & 102.9 & $x$ & 94.2 & 5.7 & 69.0 \\
\hline Catch volume composition, \% & 3.6 & 41.6 & $x$ & 54.8 & 0.0 & 100.0 \\
\hline \multicolumn{7}{|c|}{2015} \\
\hline Catch quota, t & 5408 & 25404 & 21201 & 31548 & 63 & 84121 \\
\hline Real catch volume, t & 2593 & 25266 & $x$ & 30501 & 4 & 58364 \\
\hline Volume as a \% of quota & 47.9 & 99.5 & $x$ & 96.7 & 6.3 & 69.4 \\
\hline Catch volume composition, \% & 4.4 & 43.3 & $x$ & 52.3 & 0.0 & 100.0 \\
\hline \multicolumn{7}{|c|}{2016} \\
\hline Catch quota, t & 3954 & 26234 & 19055 & 28017 & 63 & 77323 \\
\hline Real catch volume, t & 2700 & 26100 & $x$ & 28100 & 4 & 56904 \\
\hline Volume as a \% of quota & 68.3 & 99.5 & $x$ & 100.3 & 6.3 & 73.6 \\
\hline Catch volume composition, \% & 4.7 & 45.9 & $x$ & 49.4 & 0.0 & 100.0 \\
\hline $\begin{array}{l}\text { Catch volume index from base } \\
\text { year, \% }\end{array}$ & 132.5 & 111.9 & $x$ & 91.4 & 100.0 & 101.4 \\
\hline \multicolumn{7}{|c|}{2017} \\
\hline Catch quota, t & 2838 & 22448 & 16724 & 39062 & 63 & 81135 \\
\hline Catch quota composition, \% & 3.5 & 27.7 & $x$ & 48.1 & 0.1 & 100.0 \\
\hline $\begin{array}{l}\text { Catch quota index from base } \\
\text { year, } \%\end{array}$ & 42.7 & 99.1 & 86.5 & 119.6 & 90.0 & 99.7 \\
\hline
\end{tabular}

* catch quota is measured in pieces, assuming that the average fish weight is $5 \mathrm{~kg}$

Source: authors' calculations based on MoA Fisheries Department, Fisheries Yearbooks, 2014; 2015; 2016; 2017.

Sprats and Baltic herring played the most significant role in the total catch volume in the Baltic Sea and the Gulf of Riga, falling in the range from $95.3 \%$ in 2016 to $96.4 \%$ in 2014. In 2014 and 2015 , the catch volume of sprats was larger, while in 2016 the difference in catch volume between sprats and Baltic herring decreased. The catch volumes of both fishes, expressed as a percentage of the quotas, were slightly volatile from year to year - in the range of $94.2-102.9 \%$. 
The fishing enterprises of Latvia have problems to fulfil the cod quota in the Baltic Sea, as the catch volume as a percentage of the quota ranged from $30.6 \%$ in 2014 to $68.3 \% 2016$. To improve the situation and raise the efficiency of fishing cod, an amendment was made to Cabinet Regulation of 2 May 2007 No. 296 (2007) "Regulations regarding Commercial Fishing in the Territorial Waters and Economic Zone Waters" (on 13 September 2016), which allows fishing enterprises to catch cod and flatfish by fishing nets not only in the coastal waters up to 20 meters deep but also in deeper waters where the population of cod is larger.

\section{Performance of fishing enterprises in Latvia}

In Latvia, fishing rights and fleet capacity management is an important instrument for achieving one of the key Common Fisheries Policy goals - the sustainable exploitation of fish resources. According to the Ministry of Agriculture data as of 20 October 2017 (Ministry of Agriculture, Fisheries 2107), there were registered 148 licensed lessees of commercial fishing rights in the Baltic Sea and the coastal waters of the Gulf of Riga, 35 licensed lessees in the Baltic Sea and beyond the coastal zone of the Gulf of Riga and five lessees of fishing rights in international waters and the waters of other countries outside the Baltic Sea.

In the period 2014-2016 in Latvia, the largest fishing enterprises in terms of turnover, according to the annual reports, were as follows: BALTREIDS Ltd, BALTJURA SERVISS Ltd, VERGI Ltd, NORTH STAR LTD Ltd, BraDava Ltd (Table 3); in 2016, their net turnover totalled EUR $47.1 \mathrm{mln}$. or $81 \%$ of the net turnover of top 10 fishing enterprises. In 2017, the total net turnover of the top 10 fishing enterprises increased by $60.7 \%$ compared with 2014 and by $27.7 \%$ compared with 2015. The largest net turnover increase from the base year was reported by BALTJURA SERVISS Ltd - $215 \%$, BALTREIDS Ltd - $184 \%$ and A.I. un KO Ltd - $169 \%$.

Top 10 fishing enterprises in Latvia by turnover in 2014-2016

Table 3

\begin{tabular}{|l|l|c|c|c|c|c|c|c|}
\hline \multirow{2}{*}{ No } & \multicolumn{1}{|}{ Enterprise name } & \multicolumn{4}{|c|}{ Net turnover, thou. EUR } & \multicolumn{3}{c|}{$\mathbf{2 0 1 6}$} \\
\cline { 3 - 10 } & & $\mathbf{2 0 1 4}$ & $\mathbf{2 0 1 5}$ & $\mathbf{2 0 1 6}$ & $\begin{array}{c}\text { Index from } \\
\text { base year, } \\
\text { \% }\end{array}$ & $\begin{array}{c}\text { Profit, } \\
\text { thou. } \\
\text { EUR }\end{array}$ & $\begin{array}{c}\text { Profit } \\
\text { margin, } \\
\text { \% }\end{array}$ & $\begin{array}{c}\text { Number of } \\
\text { employees }\end{array}$ \\
\hline 1. & BALTREIDS Ltd & 10236 & 8318 & 18845 & 184 & 1246 & 6.61 & 27 \\
\hline 2. & BALTJURA SERVISS Ltd & - & 3767 & 8083 & 215 & 26 & 0.32 & 4 \\
\hline 3. & VERGI Ltd & 7612 & 8155 & 7887 & 104 & -152 & -1.93 & 153 \\
\hline 4. & NORTH STAR LTD* & - & 6135 & 6992 & 114 & -1171 & -16.75 & 36 \\
\hline 5. & BraDava Ltd & 5415 & 5182 & 5204 & 96 & 603 & 11.60 & 110 \\
\hline 6. & Fish farm IRBE Ltd & 4919 & 6233 & 3879 & 79 & -51 & -1.33 & 85 \\
\hline 7. & 5 B Ltd & 3603 & 3482 & 3159 & 88 & -418 & -13.24 & 12 \\
\hline $\mathbf{8 .}$ & VARITA Ltd & 1794 & 1991 & 1450 & 81 & -75 & -5.15 & 34 \\
\hline 9. & A.I. un KO Ltd & 855 & 932 & 1443 & 169 & 611 & 42.34 & 13 \\
\hline 10. & JSC KURSA, Liepaja & 1811 & 1427 & 1320 & 73 & -325 & -24.66 & 42 \\
\hline
\end{tabular}

Source: authors' calculations based on Latvijas biznesa gada..., 2017.

In 2016, among the top 10 enterprises in terms of net turnover, only four made profit, whereas six suffered losses. In 2016, the highest profit margin was reported by A.I. un Ko Ltd $(42.34 \%)$ and BraDava Ltd $(11.6 \%)$, while the largest enterprise in terms of net turnover reported only the third highest profit margin $(6.61 \%)$. It turns out that fishing enterprises in other EU Member States too are not always profitable - the fisheries in many European countries are unprofitable 
and a poor investment for taxpayers. In fact, many European fleets only continue to operate with the support of government subsidies (Schroeer A., Sakai C. et al., 2011).

The number of employees at an enterprise is not a less important indicator. Totally, the top 10 enterprises employed 516 individuals in 2016; the largest employers were VERGI Ltd with 153 employees and BraDava Ltd with 110 employees, while BALTJURA SERVISS Ltd had only four employees. In 2016 in terms of labour productivity - net turnover per employee -, the highest levels were achieved by BALTJURA SERVISS Ltd at EUR $2 \mathrm{mln}$., BALTREIDS Ltd - EUR 698 thou. and 5 B Ltd - EUR 263 thou.

\section{Conclusions, proposals, recommendations}

1) In the EU, the development of fisheries is affected by the Common Fisheries Policy that involves fleet capacity management, as allowable fleet capacity is set for the Member States. The CFP has set a target to increase fish reserves to a stable level until 2020; for this reason, the catch volumes of the Member States are limited by fishing quotas.

2) Among the EU Member States, eight countries dominate: Greece, Italy, Spain, Portugal, Croatia, France and the United Kingdom; their number of fishing vessels accounts for $78 \%$, their gross tonnage comprise $68 \%$ and their total vessel engine power represents $75 \%$ of the EU total. The number of fishing vessels of Latvia represents $0.8 \%$ of the EU total, while in terms of gross tonnage the fishing fleet of Latvia makes up $2.5 \%$ of the EU total. This means that smallcapacity vessels dominate in the fishing fleet of Latvia.

3) The fishing enterprises of Latvia have to take into account a decrease in fishing opportunities, as the catch quotas for the key fish species were reduced in the range of $1-57 \%$ for the period 2014-2017. This poses a risk to the work of fishing enterprises as there is a threat to their future existence. And most likely the amount of the fishing fleet in Latvia will decrease in future. The only quota, which was increased, was for sprats (+20\% compared with 2014), but it does not compensate the decrease in other quotas.

4) Sprats and Baltic herring played the most significant role in the total catch volume in the Baltic Sea and the Gulf of Riga, accounting for $95.3 \%$ of the total in 2016. The catch quota of cod in Baltic Sea waters was not fulfilled in the period of analysis (quota fulfilment ranged from $30.6 \%$ in 2014 to $68.3 \%$ in 2016).

5) In 2016 in Latvia, the top 10 fishing enterprises had a turnover of EUR $58.2 \mathrm{mln}$., which increased by $60.7 \%$ compared with 2014 and by $27.7 \%$ compared with 2015. In 2016, among the top 10 enterprises in terms of net turnover, only four made profit, whereas six suffered losses, and two had quite high profit margins. In 2016, the top 10 fishing enterprises employed 516 individuals and demonstrated different levels of labour productivity. This means that fishing enterprises are working in an intensive competitive environment and need to analyse the factors affecting financial performance in order to achieve better results.

\section{Acknowledgements}

The research was promoted with the support of the European Maritime and Fisheries Fund, project No. 16-00-F01101-000005 "Production of Structured Fish Mass (Minced Fish) from the Baltic Sea Fish and its Use in Fish Products". 


\section{Bibliography}

1. Baldock, D., Buckwell, A., Colsa-Perez, A., Farmer, A., Nesbit, M., Pantzar, M. (2016). The Potential Policy and Environmental Consequences for the UK of a Departure from the European Union. Prepared by: Institute for European Environmental Policy, March 2016, p.104.

2. Cabinet of Ministers of the Republic of Latvia (2007). Noteikumi Nr.296 Noteikumi par rupniecisko zveju teritorialajos udenos un ekonomiskas zonas udenos Riga 2007. gada 2. maija (Regulation No.296 "Regulations regarding Commercial Fishing in the Territorial Waters and Economic Zone Waters", Riga, 2 May 2007), "Latvijas Vestnesis", 72 (3648), 05.05.2007.

3. Carpenter, G. (2016). The EU Common Fisheries Policy has helped, not harmed, UK fisheries. 12 January 2016, p.2.

4. Community Fishing Fleet Register, 2017. Retrieved: http://ec.europa.eu/fisheries/fleet/index.cfm?method=Download.Menu\&country=LVA Access: 28.12.2017.

5. Council Regulation (EU) 2016/1903 of 28 October 2016 fixing for 2017 the fishing opportunities for certain fish stocks and groups of fish stocks applicable in the Baltic Sea and amending Regulation (EU) 2016/72, Official Journal of the European Union, 29.10.2016., L 295/1, p. 10.

6. European Commission (2016). Facts and Figures on the Common Fisheries Policy. Basic Statistical Data 2016 EDITION, 56 p. Retrieved: https://ec.europa.eu/fisheries/sites/fisheries/files/docs/body/pcp_en.pdf Access: 16.12 .2017$.

7. EUROSTAT (2017). Fishing Fleet. Retrieved: http://appsso.eurostat.ec.europa.eu/nui/show.do?dataset=fish_fleet_alt\&lang=en Access: 06.12.2017.

8. FAO (2016). The State of World Fisheries and Aquaculture 2016. Contributing to food security and nutrition for all. Rome. 200 pp.

9. Latvijas biznesa gada parskats par 2016. gadu: Zivsaimnieciba, zvejnieciba (Annual Report on Business in Latvia 2016: Fisheries, Fishing) (2017). Retrieved:

https://www.firmas.Iv/lbgpp/2017/raksti/1000000440661 Access: 02.12.2017.

10. Gonzalez, M.M., Bulian, G. (2018). Influence of Ship Dynamics Modelling on the Prediction of Fishing Vessels Roll Response in Beam and Longitudinal Waves. Ocean Engineering, Volume 148, pp. 312-330. Retrieved: https://doi.org/10.1016/j.oceaneng.2017.11.032 Access: 07.12.2017.

11. Gunnlaugsson, S.B., Saevaldsson, H. (2016). The Icelandic Fishing Industry: Its Development and Financial Performance under a Uniform Individual Quota System. Marine Policy, Volume 71, pp. 73-81. https://doi.org/10.1016/j.marpol.2016.05.018. Retrieved: http://www.sciencedirect.com/science/article/pii/S0308597X16301725 Access: 09.12.2017.

12. Ignatius, S., Haapasaari, (P. (2018). Justification Theory for the Analysis of the Socio-cultural Value of Fish and Fisheries: The Case of Baltic Salmon. Marine Policy, Volume 88, pp. 167-173. https://doi.org/10.1016/j.marpol.2017.11.007. Retrieved: http://www.sciencedirect.com/science/article/pii/S0308597X17300027 Access: 12.01.2018.

13. International Council for the Exploration of the Sea (ICES) (2017). Who we are. Retrieved: http://www.ices.dk/explore-us/who-we-are/Pages/Who-we-are.aspx Access: 22.12.2017.

14. Kindsa, A., Sysa, K., Schotteb, L., Mondelaersb, K., Poletaa, H. (2016). VALDUVIS: An Innovative Approach to Assess the Sustainability of Fishing Activities. In: Fisheries Research, No 182, pp. 158-171.

15. Laitila, T., Paulrud, A., Waldo, S. (2018). Valuation of Fishing Rights Associated with Swedish Real Estate. Journal of Forest Economics, Volume 30, pp. 25-31. https://doi.org/10.1016/j.jfe.2017.11.004. Retrieved: http://www.sciencedirect.com/science/article/pii/S1104689917302076 Access: 04.01.2018.

16. LR Zvejniecibas likums (1995) (Fishery Law of the Republic of Latvia). "Latvijas Vestnesis", 66 (349), 28.04.1995., "Zinotajs", 11, 08.06.1995.

17. Ministry of Agriculture (MoA) (2016a). Lemums Nr. 4.1-12/87 "Par rupnieciskas zvejas limitiem un to izmantosanas kartibu Baltijas jura un Rigas juras lici aiz piekrastes udeniem 2017. gada" (Decision No. 4.112/87 "On Industrial Fishing Limits and Procedures for Use thereof in the Baltic Sea and the Gulf of Riga beyond Coastal Waters in 2017").

18. Ministry of Agriculture (MoA) (2017a). Ricibas programma zivsaimniecibas attistibai 2014.- 2020. gadam, 2.2 versija (Action Programme for the Development of Fisheries 2014-2020, version 2.2), p. 132. Retrieved: https://www.zm.gov.Iv/public/files/CMS_Static_Page_Doc/00/00/01/11/33/Programme_2014LV14MFOP001 2_2_Iv.pdf Access: 03.12.2017.

19. Ministry of Agriculture (MoA) Fisheries Department (2014). Zivsaimniecibas gadagramata 2014 (Fisheries Yearbook 2014). Retrieved:

http://www.laukutikls.Iv/sites/laukutikls.Iv/files/informativie_materiali/zivsaimniecibas_gadagramata_2014. pdf Access: 05.11.2017.

20. Ministry of Agriculture (MoA) Fisheries Department (2015). Zivsaimniecibas gadagramata 2015 (Fisheries Yearbook 2015). Retrieved: http://www.laukutikls.Iv/sites/laukutikls.Iv/files/informativie_materiali/zivsgadagr_2015_web.pdf Access: 05.11.2017.

21. Ministry of Agriculture (MoA) Fisheries Department (2016b). Zivsaimniecibas gadagramata 2016 (Fisheries Yearbook 2016). Retrieved:

http://laukutikls.Iv/sites/laukutikls.Iv/files/informativie_materiali/gadagramata_2016_web_sag.pdf Access: 05.11.2017. 
22. Ministry of Agriculture (MoA) Fisheries Department (2017b). Zivsaimniecibas gadagramata 2017 (Fisheries Yearbook 2017). Retrieved:

http://laukutikls.Iv/sites/laukutikls.Iv/files/informativie_materiali/zivsaimniecibas-gadagramata-2017.pdf Access: 10.12.2017.

23. Ministry of Agriculture (MoA) Zivsaimnieciba (2017c) Zvejnieciba. Saistitie dokumenti (Fisheries. Fishing. Relevant Documents). Retrieved: https://www.zm.gov.Iv/zivsaimnieciba/statiskaslapas/zvejnieciba/apraksti?nid=700\#jump Access: 03.12.2017.

24. Pantzar, M. (2016). Brexit and Fisheries. Evidence submitted to the House of Lords EU Energy and Environment Sub-Committee 2016. Brussels, Belgium, p. 8.

25. Pilvere, I., Upite, I. (2011). Support Measures and Financial Sources for Fishery Policy in Latvia. Economic Science for Rural Development: proceedings of the international scientific conference, Nr. 26: Sustainability. Integrated and Sustainable Development. Jelgava: LLU, pp. 163-173.

26. Schroeer, A., Sakai, C., Vulperhorst, V., Białaś, A. (2011). The European Union and Fishing Subsidies. September 2011, p. 16. Retrieved:

http://baltic.oceana.org/sites/baltic.oceana.org/files/EU_Subsidies_Report_FINAL_FINAL.pdf Access: 26.12.2017.

27. State Environmental Service (SES) (2017a). The List of Latvian Vessels Holding a Special Permit for Fishing in the Gulf of Riga during 2016. Retrieved: http://www.vvd.gov.Iv/public/fs/CKFinderJava/files/Ku \%C4 \%A3i_ar_licenci_l \%C4 \%ABc \%C4 \%AB.pdf Access: 11.12.2017.

28. State Environmental Service (SES) (2017b). The list of Latvian Vessels Holding a Special Permit for Fishing COD in the Baltic Sea during 2016. Retrieved:

http://www.vvd.gov.Iv/public/fs/CKFinderJava/files/Ku \%C4 \%A3i_ar_COD_licenci.pdf Access: 11.12.2017.

29. Yates, K.L. (2014). View from the Wheelhouse: Perceptions on Marine Management from the Fishing Community and Suggestions for Improvement. Marine Policy, Volume 48, pp. 39-50. https://doi.org/10.1016/j.marpol.2014.03.002. Retrieved: http://www.sciencedirect.com/science/article/pii/S0308597X14000736 Access: 28.12.2017.

30. Zhang, D., Sikveland, M., Hermansen, Ø. (2018). Fishing Fleet Capacity and Profitability. Marine Policy, Volume 88, pp. 116-121. https://doi.org/10.1016/j.marpol.2017.11.017. Retrieved: http://www.sciencedirect.com/science/article/pii/S0308597X17302373 Access: 05.01.2018. 